\title{
Synergistic potentiation of D-fraction with vitamin $C$ as possible alternative approach for cancer therapy
}

This article was published in the following Dove Press journal:

International Journal of General Medicine

25 May 2009

Number of times this article has been viewed

\section{Sensuke Konno \\ Department of Urology, New York Medical College, Valhalla, NY, USA}

Correspondence: Sensuke Konno New York Medical College, Department of Urology, Munger Pavilion 4th Floor, Valhalla, NY 10595, USA

$\mathrm{Tel}+\mathrm{I} 9145943745$

Fax + I 9145944428

Email sensuke_konno@nymc.edu
Abstract: Maitake D-fraction or PDF is the bioactive extract of maitake mushroom (Grifola frondosa) and its active constituent is the protein-bound polysaccharide (proteoglucan), or more specifically known as $\beta$-glucan. PDF has been extensively studied and a number of its medicinal potentials/properties have been unveiled and demonstrated. Those include various physiological benefits ranging from immunomodulatory and antitumor activities to treatment for hypertension, diabetes, hypercholesterolemia, viral infections (hepatitis B and human immunodeficiency virus), and obesity. Particularly, two major biological activities of PDF, immunomodulatory and antitumor activities, have been the main target for scientific and clinical research. To demonstrate and confirm such biological activities, numerous studies have been performed in vitro and in vivo or in clinical settings. These studies showed that PDF was indeed capable of modulating immunologic and hematologic parameters, inhibiting or regressing the cancer cell growth, and even improving quality of life of cancer patients. Synergistic potentiation of PDF with vitamin $\mathrm{C}$ demonstrated in vitro is rather interesting and may have clinical implication, because such combination therapy appears to help improve the efficacy of currently ongoing cancer therapies. Recently, intravenous administration of vitamin $\mathrm{C}$ has been often used to increase its physiological concentration and this useful procedure may further make this combination therapy feasible. Therefore, PDF may have great potential, either being used solely or combined with other agents, for cancer therapy. Such relevant and detailed studies will be described and discussed herein with a special focus on the combination of PDF and vitamin $\mathrm{C}$ as a viable therapeutic option.

Keywords: maitake D-fraction, PDF, vitamin C, synergism, cancer therapy

\section{Introduction}

Mushrooms have been known for centuries particularly among Chinese and Japanese people who consumed or utilized them for dietary or medicinal purposes. However, Western people have neither known these mushrooms nor gained their potential health benefits until recently. One reason for this disparity may arise from misunderstanding or misconception about the nature and properties of mushrooms. As mushrooms belong to the family of "fungi", many (Western) people have a general perception that mushrooms have little nutritional value while others think that eating mushrooms may make one vulnerable to some yeast infections. We now know these concepts are invalid, and to the contrary, mushrooms have great nutritional value including vitamins, minerals, amino acids, and fibers; ${ }^{1}$ they are indeed healthy food. As a number of mushrooms are now cultivated worldwide, their products or extracts have become easily available to the public and sold mainly as dietary supplements. The market

submit your manuscript $\mid$ www.dovepress.con 
value of such mushroom supplement products worldwide is nearly US\$5-6 billion annually. ${ }^{2}$

In addition to their dietary value, the medicinal aspects of mushrooms have been long appreciated in the Far East but are also rapidly gaining a great public attention in the Western world. Because of an easy and abundant availability of many mushrooms by cultivation, not only the public but also scientists can obtain them for scientific and clinical research. Bioactive extracts or metabolites of these medicinal mushrooms are widely being used to treat or prevent a variety of diseases. Since these mushroom products are considered as dietary supplements, they could be individually or personally used for therapeutic purposes without going through a series of "phase trials" required for an ordinary drug/medicine under the US Food and Drug Administration (FDA). Yet, the sufficient scientific studies have not been performed on most of these mushrooms (or their products) to reveal and confirm their actual medicinal potentials/properties, although some of them have been indeed scientifically investigated. Particularly, one of them is known as "maitake mushroom" (Grifola frondosa) and its bioactive extract is named "Maitake D-fraction."

\section{Maitake D-fraction (PDF)}

Maitake mushroom is a tasty edible mushroom. Maitake literally means "dancing mushroom". It is a huge mushroom that can reach 20 inches in diameter and weigh up to 100 pounds. Besides its great taste, it has also been believed to provide health benefits and often used for therapeutic purposes. As maitake was then considered a medicinal mushroom, it has been extensively subjected to scientific studies for nearly 30 years which has revealed a number of medicinal properties that could provide remarkable health benefits. Various physiological benefits of maitake have been postulated or demonstrated, ranging from immunomodulatory and antitumor activities to treatment for hypertension, diabetes, hypercholesterolemia, obesity, and hepatitis B infection..$^{3-11}$ Its antiviral activity against human immunodeficiency virus (HIV)/AIDS was also confirmed by the US National Cancer Institute in 1992. ${ }^{12}$

The majority of maitake research described above has been performed using its bioactive extract, namely "Maitake D-fraction (PDF)". This D-fraction or PDF is the protein-bound polysaccharide or proteoglucan, consisting of $\beta$-glucan (either $\beta$-1,6-linked glucan with $\beta$-1,3 branches or $\beta$-1,3-linked glucan branched with $\beta-1,6$ glucosides; see Figure 1) as a main polysaccharide backbone where a few uncharacterized protein units are attached to. In other words, PDF is not a pure form of $\beta$-glucan that is yet a core constituent but is a "proteoglucan" having both $\beta$-glucan (major) and protein (minor) portions. This is a huge proteoglucan with a molecular weight of $\sim 1 \times 10^{6}$ Daltons, ${ }^{3,13}$ having acidinsoluble, alkali-soluble and hot water-extractable nature. ${ }^{3}$ In addition, biological activities of PDF have been shown to stem primarily from $\beta$-glucan, which was thus considered a bioactive component of PDF. ${ }^{3,5,7,-13}$ Particularly, its two major biological activities, such as immunomodulatory and antitumor activities, ${ }^{3,713}$ have been well documented and its clinical and therapeutic utilities are known.

\section{Immunomodulatory activity of PDF}

The innate immune system is the first line of defense against microbial invasion, which immediately recognizes and copes

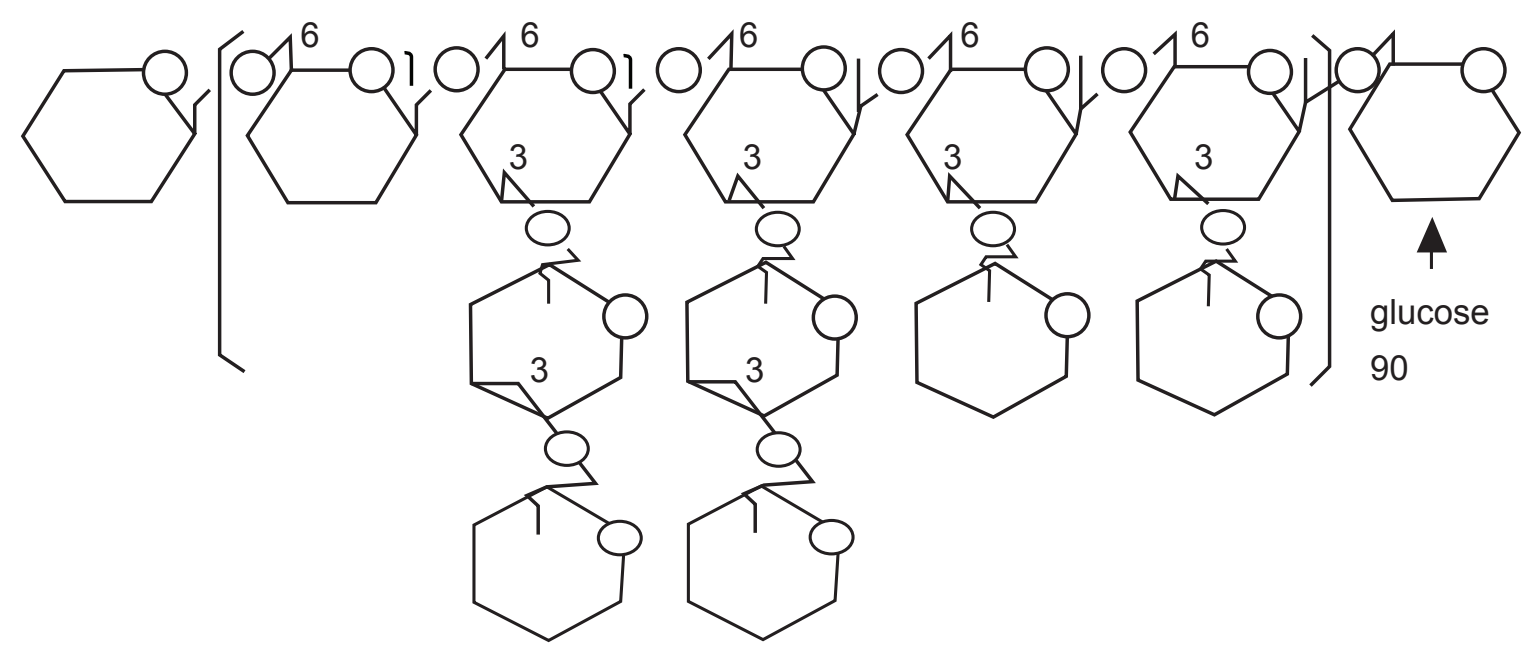

Figure I Schematic structure of $\beta$-glucan. 
with such infections. Although various $\beta$-glucans have been known to commonly exhibit immunomodulatory activity for a long time, ${ }^{14}$ such underlying cellular and molecular mechanisms have not been fully defined but were recently being unveiled. Since PDF has a core $\beta$-glucan structure for its inherent bioactivities, all immunomodulatory activities demonstrated with $\beta$-glucans would be substantially relevant to those exhibited by PDF. Such immunomodulations by $\beta$-glucans include mitogenecity and activation of immune effector cells such as lymphocytes, macrophages, dendritic cells, and natural killer (NK) cells, stimulating the production of various cytokines and chemokines such as interleukins (IL-1 $\beta$, IL-6, IL-8, IL-12 etc.), tumor necrosis factor- $\alpha$ (TNF- $\alpha$ ), and interferon- $\gamma($ IFN- $\gamma){ }^{15,16}$ However, the first step in triggering the immune-modulating effects by $\beta$-glucans requires the specific cellular receptors that recognize and bind to them. In fact, a number of " $\beta$-glucan receptors" have been identified on both immune and nonimmune cells, including macrophages, NK cells, monocytes, neutrophils, endothelial cells, fibroblasts, etc. ${ }^{17}$ Those receptors include complement receptor 3 (CR3), lactosylceramide, scavenger receptors, and Dectin-1. ${ }^{18}$ Particularly, Dectin-1 appears to be the most interesting receptor, predominantly found on macrophage/monocyte and neutrophil lineages, and can recognize soluble and particulate $\beta$-glucans. ${ }^{19}$ It then mediates a variety of cellular immune-modulating effects, such as phagocytosis, endocytosis, and the oxidative burst, and also induces the production of pro-inflammatory cytokines/ chemokines including TNF- $\alpha$, IL-12, and macrophageinflammatory protein-2 (MIP-2) $)^{18,20}$ although they could work paradoxically in a positive or negative manner, depending on microenvironments where they are regulated or interact with certain/specific factors. Nevertheless, $\beta$-glucans would activate a wide variety of innate host defenses, such as protection against infections with fungal, protozoal, bacterial, and viral pathogens, as well as prevention/protection against cancer development (carcinogenesis). This may well represent how various $\beta$-glucans or PDF would induce the immunomodulatory effects: ie, binding of $\beta$-glucans to specific receptors, triggering activation of immune effector cells, stimulating production of cytokines/chemokines, and targeting and attacking foreign pathogens and (cancer) cells.

The following studies describe various immunologic and hematologic aspects of PDF; however, it should be noted that PDF used in some of those studies were essentially all the same but not exactly the same or identical, due to changes in suppliers/manufacturers of PDF or maitake extracts during the past 30 years. Nevertheless, all data obtained from the studies used PDF or "similar maitake extracts" are fully relevant.

Effects of maitake extract on hematopoietic stem cells Recently, the effects of the maitake extract similar to PDF have been reported on mouse bone marrow cells (BMCs), describing that this extract was capable of enhancing BMC proliferation and differentiation into granulocytes-macrophages (GMs). ${ }^{21}$ In addition, the extract protected the colony formation unit (CFU) response of GMs (CFU-GM response) from doxorubicin (DOX)-induced hematopoietic suppression. ${ }^{21}$ The similar results were also obtained from the separate study using human umbilical cord blood (CB) cells: the extract induced differentiation of CB cells into CFU-GM and reduced DOX-induced hematopoietic toxicity. ${ }^{22}$ Thus, these results suggest that maitake extract may have such a potential to induce hematopoietic cell differentiation and protect those cells from the toxic effects exerted by chemotherapy. In particular, this maitake extract or PDF may have clinical implications in treatment of myelosuppression and other hematopoietic disorders/diseases.

\section{Effects of PDF on immune system in vitro or in vivo}

To assess the actual effects of PDF on the immune system or its immunomodulatory activity, a number of studies have been conducted in vitro (cell cultures) as well as in vivo (animals and humans).

As PDF has been believed to have antibacterial activity by stimulating the host immune system, its possible effects on the treatment of Listeria-infected mice in combination with vancomycine (VCM) has been investigated. Listeria monocytogenes are the gram-positive, food-mediated bacteria, causing the listeria, ${ }^{23}$ and VCM is usually the primary therapeutic modality but its high dose is known to cause various side effects. It is then feasible if the VCM dose could be reduced once combined with PDF, alleviating side effects while improving the efficacy. Such studies showed that the survival rate of Listeria-infected mice treated with the PDF/VCM combination was longer/better $(60 \%$ on the 10 th day) than those treated with VCM alone, while non-treated control mice died in three days after the inoculation. ${ }^{24}$ It was also found that macrophages in PDF/VCM-treated mice produced 2.7 times as much IL-1 as that of nontreated control mice. The bactericidal activity of T cells was also 2.6 times greater than that of control mice. Thus, these findings suggest an adjuvant role of PDF in antibacterial treatment for patients in a high risk group.

The recognition of microbes by macrophages would lead to phagocytosis, activating several enzymes including the 
inducible nitric oxide synthase (iNOS) that facilitates the production of bactericidal reactive oxygen intermediates and nitric oxide (NO). ${ }^{15}$ Such activation of iNOS with NO production is considered the macrophage-mediated immune response. Accordingly, the effects of PDF has been examined on iNOS-mediated NO production in RAW264.7 cells, a murine macrophage cell line. PDF was shown to induce iNOS-mediated NO production by RAW cells, which then significantly reduced the cell viability of human hepatomaderived huH-1 cells. ${ }^{25}$ This antitumor effect of RAW cells is thus due to activation of iNOS by PDF, not to direct cytotoxic activity of PDF on huH-1 cells, demonstrating the macrophage-mediated antitumor effect.

In the early animal studies, PDF has demonstrated immune enhancement in tumor-bearing mice: immune effector cells and cytokines such as NK cells, T lymphocytes (CTL), lymphokine-activated killer cells, IL-1 and IL-2 were all activated by 1.5-2.2-fold (compared to controls) following the PDF treatment ${ }^{26}$ (Table 1). Concurrently, the rate of cancer proliferation was significantly reduced with PDF, demonstrating its antitumor activity. These results thus suggest that PDF appears to be a potent immunomodulator, which is also capable of reducing or slowing down the cancer cell growth through its immune-modulating effects.

NK cells are a class of lymphocytes that rapidly respond to intracellular infections with viruses or bacteria, killing those infected cells and producing the macrophage-activating cytokines. However, NK cells do not express T-cell receptors that recognize specific peptides presented on the major histocompatibility complex (MHC), but they can recognize the surface changes that occur on infected cells or a variety of cancer cells. ${ }^{27} \mathrm{NK}$ cells are also known to have two relevant functions. ${ }^{28}$ One of them is cytotoxicity, mediated through the recognition and lysis of target cells such as virus- or

Table I Effects of PDF on immune effector cells and cytokines in tumor-bearing mice

\begin{tabular}{ll}
$\begin{array}{l}\text { Immune effector } \\
\text { cells/cytokines }\end{array}$ & $\begin{array}{l}\text { Activation by PDF administration } \\
\left.\text { (Relative to Control }{ }^{\text {a }} \text { value of } \mathbf{1 . 0 0}\right)\end{array}$ \\
\hline NK cells & 1.52 \\
CTL & 2.22 \\
Lymphokine-activated & 1.64 \\
killer cells & \\
IL-I & 1.98 \\
IL-2 & 1.73 \\
\hline
\end{tabular}

Note: aSaline injection.

Abbreviations: NK, natural killer; CTL, cytotoxic T lymphocytes; IL-I, interleukin I; IL-2, interleukin 2; PDF, Maitake D-fraction. bacteria-infected cells. The other function is to produce various cytokines such as IFN- $\gamma$, TNF- $\alpha$, and granulocyte/ macrophage-colony-stimulating factor (GM-CSF), which can modulate natural and specific immune responses. Such studies focusing on NK cells, ie, the effects of PDF on NK cells, have been performed in cancer patients and mice. A limited, noncontrolled clinical trials of PDF on eight cancer patients showed that cytotoxic activity of NK cells in these patients were elevated by $1.2-2.7$ times with the PDF treatment and such elevated levels were even maintained for one year. ${ }^{29}$ To elucidate the mechanism of sustained NK activity with $\mathrm{PDF}$, studies using mice and cell cultures were also performed. $\mathrm{C} 3 \mathrm{H} / \mathrm{HeN}$ mice were implanted with MM-46 breast carcinoma cells and received PDF intraperitoneally (i.p.) for 19 days. The levels of TNF- $\alpha$ and IFN- $\gamma$ released from spleen cells and TNF- $\alpha$ expression in NK cells were significantly increased in tumor-bearing mice received PDF (compared to control mice without PDF), as their tumor growths were markedly suppressed..$^{29}$ This increased TNF- $\alpha$ and IFN- $\gamma$ release is typically indicative of activation of NK cells. Moreover, the increased IL-12 secretion from macrophage RAW 264.7 cells was also demonstrated following the PDF treatment. ${ }^{29}$ Since IL-12 is critical to the functions of NK and T cells, the long-term NK cytotoxicity with PDF could be at least in part attributed to the increased IL-12 release from macrophages. NK cells could be further activated by IFN- $\gamma$ released from themselves as well as activated T cells. Similarly, in separate study activation of peripheral blood NK cells and their sustained cytotoxicity with PDF was observed in patients with lung, breast, and liver cancer. ${ }^{30}$

Besides the innate immune response primarily involving NK cells and macrophages, there is another one called the adaptive immune response that comprises $\mathrm{T}$ and $\mathrm{B}$ cells. $\mathrm{T}$ cells or CTL include T-helper (Th) cells and cytotoxic $\mathrm{T}$ (Tc) cells. Th cells activate B cells to secrete antibodies targeting foreign antigens (known as the antibody response), while Tc cells attack and destroy infected host cells with pathogens (as the cell-mediated immune response). ${ }^{31} \mathrm{Th}$ cells can be also classified into Th- 1 and Th- 2 cells according to the types of cytokines they produce. Th- 1 cells produce IL-2, IFN- $\gamma$, and TNF- $\beta$ (introducing cellular immunity to the organisms), while Th-2 cells produce IL-4, IL-5, IL-6, IL-10, and IL-13 (activating humoral immunity). ${ }^{32}$ One study showed that PDF decreased $\mathrm{B}$ cell activation but increased Th- 1 cell activation in tumor-bearing $\mathrm{C} 3 \mathrm{H} / \mathrm{HeN}$ mice, resulting in enhanced cellular immunity. PDF also stimulated the production of IFN- $\gamma$, IL-12p70, and IL-18, but suppressed IL-4 production. ${ }^{33}$ These results then suggest that PDF may 
establish Th-1 dominance that induces cellular immunity in the population with Th-2 dominance due to carcinoma.

It was yet of interest to perform the same study above using "BALB/c" mice (instead of $\mathrm{C} 3 \mathrm{H} / \mathrm{HeN}$ mice), because they have been genetically altered to have a "Th-2" dominant response. Such study then revealed that PDF was capable of inducing the differentiation of tumor-bearing $\mathrm{BALB} / \mathrm{c}$ mice with the Th- 2 response into the Th- 1 dominant response, mediated through enhancement of IL-12p70 production by dendritic cells (DCs), which were antigen-presenting cells (APCs) with a unique ability to activate both Th and Tc cells and produce IL-12 and INF- $\gamma{ }^{34,35}$ These results thus suggest that PDF may stimulate DCs, through activation of macrophages and NK cells, inducing innate T cells into Th-1 cells.

\section{Effects of maitake extract or PDF on immunologic or hematologic parameters in cancer patients or normal subjects in controlled clinical trials}

It has been recently reported that the maitake extract (similar to PDF) was used in a phase I/II trial of breast cancer patients to assess its immunologic effects. Thirty-four postmenopausal breast cancer patients, free of disease after the initial treatment, followed an oral regimen of this maitake extract for three weeks and various immunologic parameters were analyzed. ${ }^{36}$ No apparent toxicity of the extract was observed but there was a statistically significant association between the extract and immunologic function: some immunologic parameters were upregulated with the extract while others were downregulated. For example, depending upon the dosage of the extract given, $\mathrm{CD} 3^{+} / \mathrm{CD} 25^{+}, \mathrm{CD} 4^{+} / \mathrm{CD} 25^{+}$, IL-2, or IL-10 was significantly increased but IFN- $\gamma$ production was decreased. This is indicative of the modulation of cellmediated immunity with the extract. Thus, these results show that oral administration of this extract indeed modulates immunologic parameters in these cancer patients, so that they should be aware that it could stimulate as well as depress their immune function.

This study may then raise the question on how such maitake extract or PDF would affect "healthy individuals", and such study has been also conducted. Twenty-eight healthy subjects participated in a randomized double-blinded trial of PDF for one month. Various hematologic parameters including complete blood count, serum glucose, total cholesterol and high-density lipoprotein (HDL), bilirubin, creatinin, hepatic enzymes, etc. were evaluated before and after a one-month PDF regimen. ${ }^{37}$ All hematologic data were subjected to statistical analysis and summarized in Table 2. First of all, no participants presented palpable ailments or adverse effects during the trial. Second, no substantial and clear differences/changes in 24 parameters tested were seen between the control and the PDF groups after this one-month trial. However, significant statistical differences $(p<0.05)$ in hemoglobin, hematocrit, eosinophils, mean corpuscular volume (MCV), cholesterol, triglycerides, creatinin, alkaline phosphatase, glutamic-pyruvic transaminase/alanine aminotransferase (GPT/ALT), and glutamic-oxaloacetic transaminase/aspartate aminotransferase (GOT/AST) were seen in between the PDF and placebo groups. In addition, although the differences may not be clearly significant, those in red blood cells (RBC), lymphocytes, mean corpuscular hemoglobin $(\mathrm{MCH})$, mean corpuscular hemoglobin concentration $(\mathrm{MCHC})$, and HDL were yet nearly statistically significant $(0.05<\mathrm{p}<0.1)$. Moreover, there was the

Table 2 Effects of PDF on hematological parameters in human subjects

\begin{tabular}{|c|c|c|}
\hline Parameters & Placebo vs PDF & $\begin{array}{l}\text { Statistical } \\
\text { significance }\end{array}$ \\
\hline RBC count & $p=0.082$ & $N / S$ \\
\hline WBC count & $p>0.1$ & $N / S$ \\
\hline Hemoglobin & $p<0.05$ & Significant \\
\hline Hematocrit & $p<0.05$ & Significant \\
\hline Lymphocytes & $p=0.082$ & $N / S$ \\
\hline Platelets & $p>0.1$ & $N / S$ \\
\hline Monocytes & $p>0.1$ & $N / S$ \\
\hline Granulocytes (eosinophil) & $p<0.05$ & Significant \\
\hline Granulocytes (neutrophil) & $p>0.1$ & $N / S$ \\
\hline Granulocytes (basophil) & $p>0.1$ & $N / S$ \\
\hline $\mathrm{MCV}$ & $p<0.05$ & Significant \\
\hline $\mathrm{MCH}$ & $p=0.059$ & $N / S$ \\
\hline $\mathrm{MCHC}$ & $p=0.08 I$ & $N / S$ \\
\hline Glucose & $p>0.1$ & $\mathrm{~N} / \mathrm{S}$ \\
\hline Cholesterol (total) & $p<0.05$ & Significant \\
\hline $\mathrm{HDL}$ & $p=0.082$ & $N / S$ \\
\hline Triglycerides & $p<0.05$ & Significant \\
\hline Creatinin & $p<0.05$ & Significant \\
\hline Alkaline phosphatase & $p<0.05$ & Significant \\
\hline GPT/ALT & $p<0.05$ & Significant \\
\hline GOT/AST & $p<0.05$ & Significant \\
\hline Bilirubin & $p=0.051$ & $N / S$ \\
\hline Transferrin & $p=0.068$ & $N / S$ \\
\hline Iron & $p>0.1$ & $N / S$ \\
\hline
\end{tabular}

Abbreviations: N/S, not significant; RBC, red blood cell;WBC, white blood cell; MCV, mean corpuscular volume; $\mathrm{MCH}$, mean corpuscular hemoglobin; $\mathrm{MCHC}$, mean corpuscular hemoglobin concentration; HDL, high-density lipoprotein; GPT, glutamic-pyruvic transaminase; ALT, alanine aminotransferase; GOT, glutamic-oxaloacetic transaminase; AST, aspartate aminotransferase; PDF, Maitake D-fraction. 
possible time trend (prediction) that the differences in some parameters could become significant in the long term (ie, longer than one month of this trial). One may then speculate; for example, the decreased creatinin concentration $(p<0.05)$ with PDF could indicate the improved renal function, while the reduced levels of GPT/ALT and GOT/AST indicate the improved liver function with the reduced hepatic cell injury. Similarly, the decreased cholesterol and triglyceride levels $(p<0.05$ ) could be indicative of the improved lipid metabolism, preventing potential adverse sequels associated with cardiovascular disease. Apart from these speculations, this study yet confirms that PDF undoubtedly has certain hematologic effects on normal subjects and larger randomized studies are thus required for demonstrating its potential health benefits.

\section{Antitumor/anticancer activity of PDF}

Peculiarly it has been known that many mushroom extracts were ineffective when given orally to animals bearing cancers, although they could be effective or exhibit antitumor activity when administered intravenously or intraperitoneally. ${ }^{38}$ However, a number of studies have then demonstrated antitumor activity of orally administered PDF in vivo, which was mainly associated with its immunomodulatory activity described above.

When an allogeneic Sarcoma-180 tumor was implanted into ICR-nu/nu mice (lacking matured T cells), orally administered PDF was capable of inhibiting the tumor growth by $88 \%$ compared to control mice (no PDF received). ${ }^{39}$ The similar results were also obtained from the studies using different mice bearing some syngeneic tumors. Following oral PDF administration, $\mathrm{C} 3 \mathrm{H} / \mathrm{HeN}$ mice bearing MM-46 carcinoma (breast cancer), CDF1 mice with IMC carcinoma (skin cancer), and C57BL/6 mice with B-16 melanoma (skin cancer) showed tumor inhibition of $64 \%, 75 \%$, and $27 \%$, respectively. ${ }^{39}$ These results are summarized in Table 3 . It is thus practical that oral administration of PDF would allow us its easy intake for a clinical utility.

Another interesting study was to assess whether PDF might prevent carcinogenesis (cancer development) in normal cells, ie, anticarcinogenic activity. A known carcinogen, N-nitrosodi-n-butylamine (NDBA), was given to mice with food: the control group received only normal feed (with NDBA) while the PDF group received food (with NDBA) and oral PDF supplement. After 60 days, the number of tumors appearing or developing in the liver was determined. The cancer incidence rate in the PDF group was merely $\sim 10 \%$ compared to that in the control group $(100 \%$ as the number of cancer cells found). ${ }^{40} \mathrm{~A}$ similar study using another known carcinogen, 3-methylcholanthrene (3-MCA), on mice has been also conducted. An injection of 3-MCA (suspended in olive oil) was given to the back of mice $(n=10$ /group) once, and PDF or saline solution (control) was orally administered on the 15 th day for 15 consecutive days. After 30 days, the number of mice with cancer was $\sim 93 \%$ in the control group but only $31 \%$ in the PDF group. ${ }^{41}$ These findings suggest that PDF appears to significantly prevent carcinogenesis or may have anticarcinogenic activity.

A critical issue following carcinogenesis is to slow down cancer progression or inhibit cancer metastasis, and such antimetastatic activity of PDF has been also investigated using tumor-bearing mice. MM-164 liver carcinoma was injected into the left rear footpad of mice, which was then amputated after two days. Either normal food alone (control) or that with PDF was given to (amputated) mice daily, and after 30 days the number of tumor foci metastasized to the liver was determined. Compared to the control group, cancer metastasis to the liver was remarkably prevented by over $90 \%$ in the PDF group. ${ }^{40}$ In another study, MM-46 breast carcinoma was intraperitoneally implanted in $\mathrm{C} 3 \mathrm{H} / \mathrm{HeN}$ mice and subsequently the palpable tumor formed $(\sim 7 \mathrm{~mm}$ in diameter) was surgically removed. PDF or saline (control) was then given to mice for 10 consecutive days and the tumor foci spread to other organs were assessed in sacrificed mice. The tumor metastasis (the number of metastasized tumor foci found) was inhibited by $92 \%$ in the PDF group whereas no such inhibition $(0 \%)$ was seen in the control group. ${ }^{41}$ Thus, PDF may have antimetastatic activity (preventing tumor metastasis), presumably activating immune-competent cells that would then necrotize tumor cells present in the blood and/or lymphatic vessels.

Moreover, it has been reported that the combination of PDF and mitomycin C (MMC), a chemotherapeutic drug, exhibited the augmented antitumor activity in vivo. In this

Table 3 Antitumor effect of PDF on tumor-bearing mice

\begin{tabular}{lll}
\hline Tumor system & Mice & $\begin{array}{l}\text { Growth inhibition } \\
\text { (\% relative to control) }\end{array}$ \\
\hline $\begin{array}{l}\text { Allogeneic tumor } \\
\text { Sarcoma I80 }\end{array}$ & ICR-nu/nu & $88 \%$ \\
Syngeneic tumors & & \\
MM-46 breast carcinoma & $\mathrm{C} 3 \mathrm{H} / \mathrm{HeN}$ & $64 \%$ \\
IMC skin carcinoma & $\mathrm{CDFI}$ & $75 \%$ \\
B-16 melanoma & C57BL/6 & $27 \%$ \\
\hline
\end{tabular}

Abbreviations: PDF, Maitake D-fraction. 
study, tumor-bearing mice received PDF alone showed the greater tumor growth inhibition $(\sim 80 \%)$ than that $(\sim 30 \%)$ in those received MMC alone. When PDF and MMC were given together (by cutting each initial dose by half) to mice, the tumor growth was almost completely (98\%) inhibited. ${ }^{26}$ Such enhanced antitumor effect of PDF and MMC might be explained by the stimulated immune response with PDF (as an immunomodulatory) and by a direct cytotoxic effect of MMC on tumor cells. Thus, it is plausible that PDF could be used as an adjuvant agent for chemotherapy in cancer patients.

\section{Clinical trials of PDF on cancer patients}

Regarding clinical trials of PDF, not many human trials have been performed and only a few information are available. Yet, a nonrandomized clinical study of PDF on 165 patients with various types of advanced cancers has been conducted in Japan. ${ }^{26}$ Such study showed that tumor regression or significant symptomatic improvements with PDF were observed in 73\% of breast cancer patients, $67 \%$ of lung cancer patients and $47 \%$ of liver cancer patients. When PDF was given to the patients receiving chemotherapy, the response rates have improved from $12 \%$ to $28 \%$. Overall, this study illustrated that the clinical status of patients with breast, prostate, lung, and liver cancers was significantly improved with PDF, while less effective on those with bone and stomach cancers or leukemias. ${ }^{26,42}$ In addition, interestingly various side effects of chemotherapy on all types of cancer patients were ameliorated with PDF administration. It is well known that chemotherapy often lowers or damage the immune system, but PDF may help maintain optimal activities of key immune-competent cells, minimizing such side effects. In fact, adverse symptoms such as nausea, hair loss, and leukopenia have been alleviated in $90 \%$ of those patients, while a reduction in pain was reported in $83 \%$ of patients. ${ }^{26}$ Thus, PDF appears to improve quality of life in patients and might be considered a useful adjuvant in ongoing cancer chemotherapy.

In addition, following PDF having been exempted from a phase I toxicology test by the FDA in early 1990's, it has been also approved for the investigational new drug (IND) application for a phase II pilot study on patients with advanced breast and prostate cancer. ${ }^{43}$ Among the ongoing FDA-sanctioned PDF studies on prostate cancer patients, it would be worthwhile briefly mentioning some of prostate cancer cases. ${ }^{44}$ The patients with prostate cancer have orally received the appropriate amounts (calculated from the body weight) of PDF daily with 2,000 $\mathrm{mg}$ vitamin C (VC) and were evaluated for general condition, blood chemistry, and immune status (eg, activities of NK cells and CTL). Additionally, the levels of serum prostate-specific antigen (PSA), a widely used biochemical marker for prostate cancer, were measured for assessing the disease status of these patients.

\section{Case I}

A 68-year-old patient was diagnosed for prostate cancer with the initial PSA of $20 \mathrm{ng} / \mathrm{ml}$ (a normal PSA range: $<4.0 \mathrm{ng} / \mathrm{ml}$ ) in 1998. His PSA steadily went up every year till 2000, indicating a possible progression of disease. After he started taking PDF with VC in 2001, his PSA came down significantly in three months and all other parameters looked also stable since then. Thus, this report suggests that cancer progression might have been slowed down or stopped by PDF.

\section{Case 2}

The initial PSA of $7 \mathrm{ng} / \mathrm{ml}$ (in 1995) in a 72-year-old patient declined to $1.7 \mathrm{ng} / \mathrm{ml}$ by 2000 following primary hormonal therapy. He appeared to be in disease remission, but his PSA started rising again in June of 2001 and went up further to $3.9 \mathrm{ng} / \mathrm{ml}$ by September, indicating a possible recurrence or progression of cancer. He was placed immediately in a PDF regimen and his PSA gradually came down to $2.2 \mathrm{ng} / \mathrm{ml}$ by three months. This report also suggests that PDF may slow down or stop cancer progression.

\section{Case 3}

This is rather an interesting case with a high Gleason score of 7 (while PSA was $8 \mathrm{ng} / \mathrm{ml}$ ) in a 65-year-old patient. "Gleason score" is a pathological grading system of $1-10$ based on the histological examination of biopsy specimen, ${ }^{45}$ helping us assess a probability of having cancer metastasis: in general, the higher score indicates the greater risk of metastasis. Since his initial PSA had not notably come down in two years, he decided to have a surgery (radical prostatectomy) in 2001. His PSA went down significantly to $2 \mathrm{ng} / \mathrm{ml}$ in a month after his surgery, although we were yet concerned about possible metastasis because of his high Gleason score. As a precaution, he then started taking PDF and his PSA further declined to $<0.1 \mathrm{ng} / \mathrm{ml}$ in six months. His prognosis was good with all parameters being normal. This report suggests that PDF may also suppress metastatic disease or stop cancer progression to a fatal hormone-refractory state, although it is possible that surgery could have completely removed the tumor before metastasis started up.

These case studies suggest that PDF may help lower the serum PSA levels in prostate cancer patients and probably slows down or prevents disease progression or metastasis. We also found that PDF appeared to sustain the high levels of NK cell and CTL activities, indicating an alert immune surveillance, and to improve physical/mental soundness and 
quality of life of these patients. Taken all together, PDF is indeed safe to cancer patients (as well as healthy subjects ${ }^{37}$ ) and may also offer some health benefits, comfort, and hope to those patients.

\section{Synergistic potentiation of PDF with vitamin $\mathbf{C}$}

Vitamin C (VC) or ascorbic acid could be the most popular nutritional supplement known and taken by numerous people. $\mathrm{VC}$ is a water-soluble antioxidant that can scavenge free radicals, thereby protecting the cells from lethal oxidative stress. ${ }^{46}$ Interestingly, $\mathrm{VC}$ may also act as a pro-oxidant to generate free radicals, particularly through the reduction of metal ions such as iron or copper: this is known as the Fenton reaction. ${ }^{47} \mathrm{In}$ other words, $\mathrm{VC}$ has a dual role that can act as an antioxidant or a pro-oxidant, depending upon its (high) cellular concentrations and the availability/presence of cellular iron.

Besides such redox properties of $\mathrm{VC}$, it has been well documented that $\mathrm{VC}$ also had anticancer effect on various cancer cells in vitro, due to its pro-oxidant activity to generate free radical (hydrogen peroxide, $\mathrm{H}_{2} \mathrm{O}_{2}$ ) rather than its popular antioxidant action. ${ }^{48}$ Yet, another important question is whether VC would be able to actually induce such generation of free radicals (particularly $\mathrm{H}_{2} \mathrm{O}_{2}$ ) in vivo. It has been then shown that a measurable or significant amount of $\mathrm{H}_{2} \mathrm{O}_{2}$ was indeed generated with the high concentrations of $\mathrm{VC}$ achieved through its intravenous (i.v) administration in mice. ${ }^{49}$ Such a mechanism(s) is not completely understood but it may likely involve or interact with some protein-bound metal cations. In addition, this $\mathrm{VC}$-mediated $\mathrm{H}_{2} \mathrm{O}_{2}$ production in vivo appears to only take place in extracellular fluids, not in blood, since antioxidant enzymes (eg, catalase, glutathione peroxidase, etc.) present in erythrocytes could efficiently remove or scavenge $\mathrm{H}_{2} \mathrm{O}_{2} \cdot{ }^{50} \mathrm{VC}$ has been also reported to promote the efficacy of several chemotherapeutic drugs in vivo $;{ }^{51}$ however, the oral administration of $\mathrm{VC}(6,100 \mathrm{mg})$ had no effects on patients undergoing chemotherapy ${ }^{52}$ and even the higher VC dose (10 g) was ineffective on patients with advanced cancer. ${ }^{53}$ Moreover, pharmacokinetic studies revealed that the oral administration of $\mathrm{VC}$ would not achieve its plasma concentrations higher than $50-100 \mu \mathrm{M} .{ }^{54}$ However, the phase I trial of the iv administration of $\mathrm{VC}$ to cancer patients has reported that the high-dose $\mathrm{VC}$ instillation demonstrated anticancer effect. In this study, the iv infusion of $\mathrm{VC}$ allowed an injection of the extremely high $\mathrm{VC}$ doses up to $1.5 \mathrm{~g} / \mathrm{kg}$ (body weight) in cancer patients, raising their plasma concentrations $>10 \mathrm{mM}$ for over four hours, which have been previously shown to be sufficient to induce cancer cell death in vitro. ${ }^{55}$ This new approach of iv administration of VC to achieve its therapeutic (effective) plasma level as an adjuvant therapy is becoming popular but yet remains controversial in the absence of sufficient and reliable clinical data. Thus, further clinical studies are warranted to collect more data to adequately address the true efficacy of $\mathrm{VC}$ in cancer therapy.

\section{Synergism: Enhanced PDF activity with VC}

Apart from various aspects of $\mathrm{VC}$ described above, it was rather interesting for us to learn that $\mathrm{VC}$ had been postulated to enhance bioactivity of mushroom extract or specifically $\beta$-glucans, ${ }^{56}$ although the exact mechanism needs to be yet defined. Since PDF has $\beta$-glucan as its major bioactive element mentioned earlier and could be potentiated with $\mathrm{VC}$, it was reasonable that $\mathrm{VC}$ had been included in the PDF regimen for prostate cancer patients described above, although the actual effects of VC with PDF have not yet been addressed. To examine such combined effects of PDF and VC on cancer cells, we performed the in vitro study using human prostate cancer PC-3 cells as our experimental model. This study has been published previously, ${ }^{57}$ but it should be noted that making the concentrations of PDF used in all studies comparable or relevant, these values have been normalized in the following studies described because the stock PDF concentrations had varied with some modifications made on formulating PDF by the manufacturer.

\section{Effects of PDF or VC on PC-3 cell growth}

Prostate cancer is the second-leading cause of cancer death in elderly men in the United States. Although several conventional therapies including androgen ablation, chemotherapy, brachytherapy (radioactive seeds implant), radiotherapy, immunotherapy, surgery, etc. are currently available, none of them has yet been able to achieve the expected level of efficacy. ${ }^{58,59}$ Thus, exploring and establishing a more effective modality for prostate cancer treatment is urgently demanded. As an alternative unconventional approach, we examined if PDF might inhibit or slow down the growth of human prostate cancer PC-3 cells, derived from a patient with bone metastasis. ${ }^{60}$

PC-3 cells were cultured with the varying concentrations $(0-1,000 \mu \mathrm{g} / \mathrm{ml})$ of PDF and cell number and viability were assessed in $72 \mathrm{~h}$. This dose-response study showed that no effects of PDF was seen up to $250 \mu \mathrm{g} / \mathrm{ml}$ but a marginal $(\sim 15 \%)$ and significant $(\sim 65 \%)$ growth reduction was observed at 500 and $1,000 \mu \mathrm{g} / \mathrm{ml}$, respectively (Figure 2). When cells were cultured with a varying concentration $(0-1,000 \mu \mathrm{M})$ of $\mathrm{VC}$, no apparent effects were seen up to $300 \mu \mathrm{M}$, a little over 


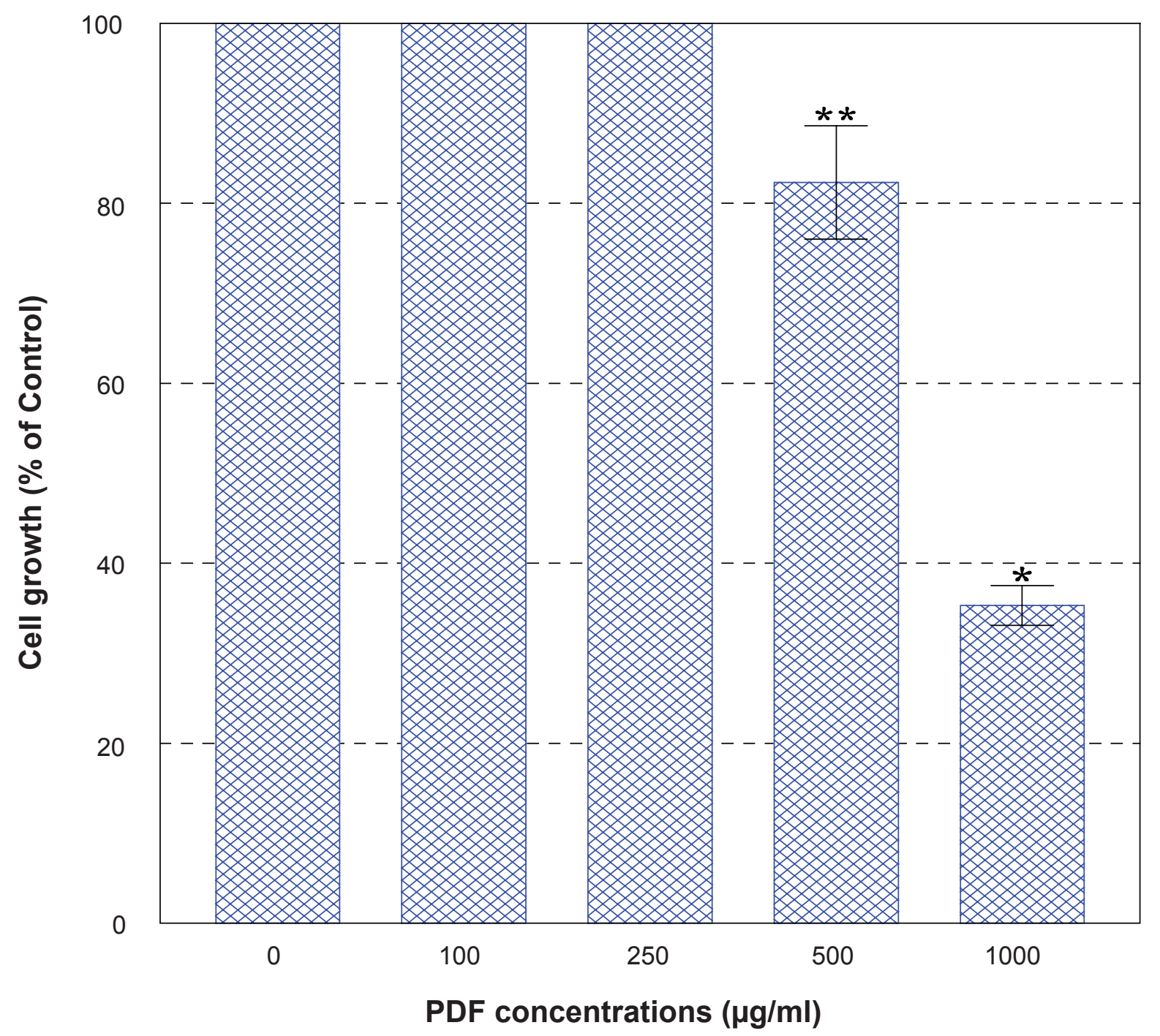

Figure 2 Effect of PDF on PC-3 cell growth. PC-3 cells were cultured with the varying concentrations of PDF (0-I,000 $\mu \mathrm{g} / \mathrm{ml})$, and viable cell numbers were determined in $72 \mathrm{~h}$. All data represent mean \pm SD from three separate experiments.

Notes: ${ }^{\mathrm{p}}<0.02$; **p $<0.08$.

Abbreviations: PC-3, human prostate carcinoma cell line; PDF, Maitake D-fraction; SD, standard deviation.

$50 \%$ reduction in cell viability was attained with $500 \mu \mathrm{M}$, and nearly complete cell death ( $\sim 0 \%$ cell viability) was observed with $1,000 \mu \mathrm{M}$ in $72 \mathrm{~h}$ (Figure 3). Thus, these results show that PDF is capable of inhibiting cell growth at a high concentration and VC appears to also induce significant cell death at its concentrations $\geq 500 \mu \mathrm{M}$.

\section{Synergistic effects of PDF combined with VC on PC-3 cell growth}

Since it would be practical if such a high concentration of PDF required could be somehow lowered without losing its potency, we next examined whether VC might help augment PDF potency as it has been postulated above. ${ }^{56} \mathrm{PC}-3$ cells were treated for $24 \mathrm{~h}$ with the relatively low, ineffective concentrations $(0-250 \mu \mathrm{g} / \mathrm{ml}$ ) of PDF (Figure 2 ) in combination with the similarly ineffective concentrations $(0-200 \mu \mathrm{M})$ of VC (Figure 3). Among various combinations tested, particularly the combination of $150 \mu \mathrm{g} / \mathrm{ml} \mathrm{PDF}$ and $200 \mu \mathrm{M} \mathrm{VC}$ resulted in $>90 \%$ cell death in $24 \mathrm{~h}$ (Figure 4). Since neither $150 \mu \mathrm{g} / \mathrm{ml}$ PDF nor $200 \mu \mathrm{M}$ VC alone showed any effects on cell growth/viability, the resulting $>90 \%$ cell death induced with this particular PDF/VC combination is more likely attributed to a synergistic potentiation of these two agents. It is then plausible that $\mathrm{VC}$ may primarily serve as an adjuvant factor to augment the PDF activity. Therefore, this finding is significant and suggests that the relatively low concentrations of PDF with no cytotoxic activity could be yet synergistically potentiated with VC to become highly cytotoxic to PC-3 cells. 


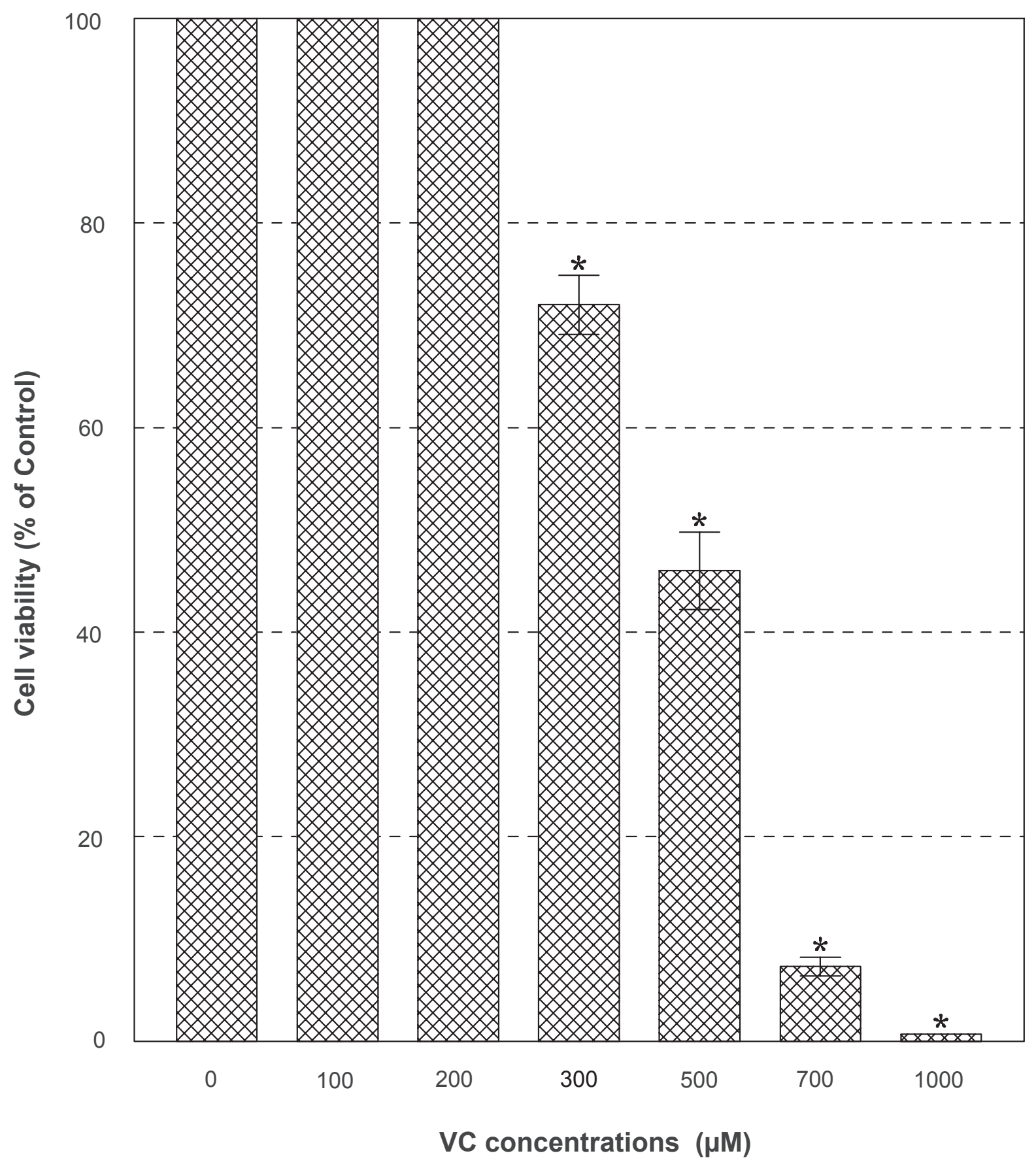

Figure 3 Effect of VC. PC-3 cells were cultured with the indicated concentrations of VC, and viable cell numbers were determined in $72 \mathrm{~h}$. All data are mean \pm SD from three independent experiments.

Note: $*_{p}<0.05$

Abbreviations: PC-3, human prostate carcinoma cell line; SD, standard deviation; VC, vitamin C.

Oxidative stress exerted by PDF/VC combination

To explore the cytotoxic mechanism of the PDF/VC combination, possible involvement of oxidative stress (generation of free radicals) was investigated. We observed "cell blebbing" (cytoplasmic vesicle formation) in PC-3 cells treated with the PDF/VC combination (data not shown), which was indicative of the cells under oxidative stress. ${ }^{61}$
As mentioned earlier, cytotoxic activity of $\mathrm{VC}$ in vitro has been shown and believed to be associated with oxidative stress, particularly generation of $\mathrm{H}_{2} \mathrm{O}_{2} \cdot{ }^{48}$ Accordingly, lipid peroxidation (LPO) assay was performed on the cells exposed to the combination of PDF $(150 \mu \mathrm{g} / \mathrm{ml})$ and VC $(200 \mu \mathrm{M})$ for merely three hours, which should have been sufficient to exert oxidative stress. This PLO assay has been 


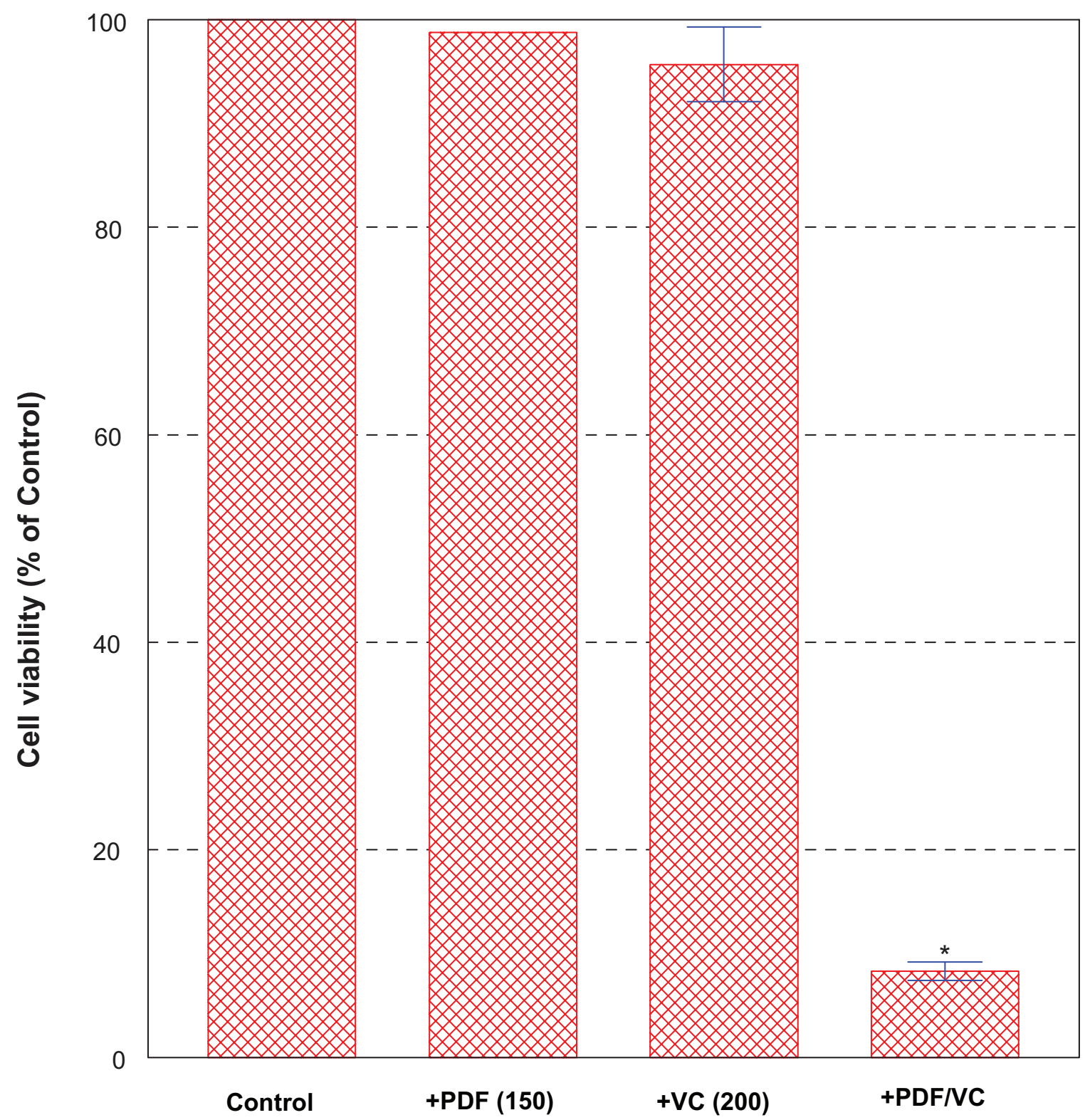

Figure 4 Effects of PDF/VC combination on cell viability. PC-3 cells were treated for $24 \mathrm{~h}$ with the ineffective concentrations $(0-250 \mu \mathrm{g} / \mathrm{ml})$ of PDF in combination with the similarly ineffective concentrations (0-200 $\mu \mathrm{M})$ of VC. Particularly, the combination of I50 $\mu \mathrm{g} / \mathrm{ml} \mathrm{PDF}$ and $200 \mu \mathrm{MVC}$ resulted in $>90 \%$ cell death $(* \mathrm{p}<0.01)$ as shown here. Abbreviations: PC-3, human prostate carcinoma cell line; PDF, Maitake D-fraction; VC, vitamin C.

often used for assessing possible damage or perturbation in the plasma membrane due to oxidative stress, by measuring the amount of malondialdehyde (MDA) formed, an end product from peroxidation of polyunsaturated fatty acids in the plasma membrane. ${ }^{62}$ Such analyses then revealed that the LPO level in PDF/VC-exposed cells was almost two-fold higher than those in control, sole PDF- or sole VC-exposed cells (Figure 5). This finding indicates that significant plasma membrane damage has occurred in PDF/VC-exposed cells, mediated through severe oxidative stress, causing cellular turmoil and ultimately leading to cell death. ${ }^{63}$ Thus, these results support the notion that $\mathrm{PDF} / \mathrm{VC}$-induced cell death is at least in part due to oxidative stress, presumably through $\mathrm{H}_{2} \mathrm{O}_{2}$ generated.

However, one may raise some concern for a clinical utility of PDF/VC combination because their cytotoxic mechanism appears to be primarily attributed to oxidative stress. It is conceivable that such resulting oxidative stress could cause a nonspecific random damage to even normal cells (as well as cancer cells). Interestingly, it has been shown that cancer cells were generally more vulnerable to oxidative stress than normal cells. ${ }^{64}$ Although the reason(s) for a different susceptibility of 


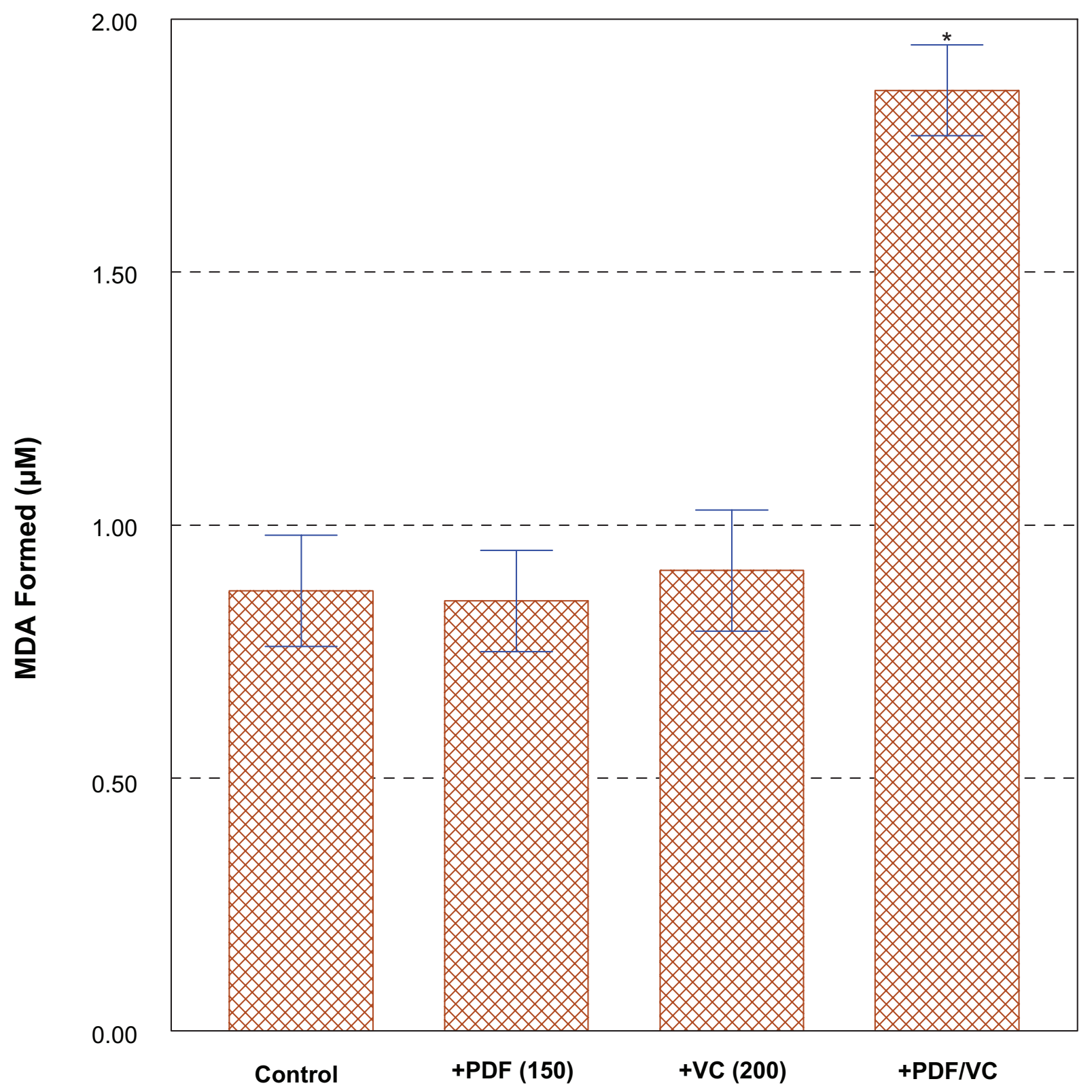

Figure 5 Assessment of lipid peroxidation (LPO) level with PDF/VC combination. Cells were exposed to the combination of PDF (I50 $\mu g / \mathrm{ml})$ and VC (200 $\mu \mathrm{M})$ for merely $3 \mathrm{~h}$, and the LPO levels in control, PDF alone-,VC alone-, and PDF/VC-exposed cells were determined for comparison, by measuring the amount of malondialdehyde (MDA) formed. The data are mean \pm SD from three separate experiments.

Notes: ${ }^{*} p<0.01$.

Abbreviations: PDF, Maitake D-fraction; SD, standard deviation; VC, vitamin C.

these cells is not fully understood, several evidences suggest that it may result from the inherent difference in antioxidant enzymes whose primary function is to scavenge harmful free radicals. For example, two common antioxidant enzymes, catalase and glutathione peroxidase, have been found to be often deficient or have a significantly low activity in cancer cells. ${ }^{65}$ Thus, a difference in cellular antioxidant enzymes may at least account for a different susceptibility of normal and cancer cells to oxidative stress. It is then plausible that oxidative stress exerted by the PDF/VC combination could be high or severe enough to kill cancer cells but might not be severe enough for normal cells because those free radicals could be effectively scavenged by active antioxidant enzymes. As a result, oxidative stress exerted by the PDF/VC combination would likely kill cancer cells whereas normal cells may remain safe and intact. Therefore, the PDF/VC combination appears to effectively and selectively target cancer cells, implying their clinical/therapeutic utility. 


\section{Induction of apoptosis by PDF/VC combination}

The next valid question is exactly how PC-3 cells would die from the PDF/VC treatment, whether they may die with necrosis or apoptosis (programmed cell death). Despite a drastic reduction $(>90 \%)$ in cell viability induced by the PDF/VC combination, cell fragmentation or disintegration was rarely observed, indicating that such cell death would be unlikely due to necrosis. Accordingly, we performed in situ hybridization (ISH) assay to test possible induction of apoptosis by the PDF/VC combination. ISH analyses then revealed that the cells treated with the combination of PDF $(150 \mu \mathrm{g} / \mathrm{ml})$ and $\mathrm{VC}(200 \mu \mathrm{M})$ for $24 \mathrm{~h}$ exhibited a positive brown staining (Figure 6B) while a negative staining was seen in control cells (Figure 6A). Since distinctly fragmented DNA can be stained (giving off brown color) with ISH assay, its positive staining is indicative of apoptotic cell death. ${ }^{66}$ Thus, these results suggest that PDF/VC-induced cell death most likely results from apoptosis or follows the apoptotic pathway.

\section{Combined effects of PDF and chemotherapeutic drugs}

It was of interest to further examine whether cytotoxic activity of PDF/VC combination could be comparable to that of chemotherapeutic drugs, and VC or PDF might also act as the adjuvant agents to potentiate those drugs. As prostate cancer has been known to be highly resistant to chemotherapy ${ }^{67}$ it would be certainly beneficial if such a poor efficacy of these drugs could be somehow improved.

Accordingly, PC-3 cells were treated solely with various chemotherapeutic drugs, including vinblastine (VBL), 5-fluorouracil (5-FU), methotrexate (MTX), etoposide (VP-16), cisplatin (CPL), cyclophosphamide (CyP), mitomycin C (Mit.C), and carmustine (BCNU), or in combination with $\mathrm{VC}(200 \mu \mathrm{M})$ or PDF $(150 \mu \mathrm{g} / \mathrm{ml})$. To attain the optimal efficacy of each drug in vitro, the concentrations of drugs used here were the estimated maximum or above physiologically tolerable levels. Cell viability at each condition was then assessed in $72 \mathrm{~h}$ and the results are summarized in Table 4. However, as $\mathrm{VC}$ was found to have no effects on improving cytotoxicity of all drugs, these results have been omitted from Table 4 . Although some of those drugs (BCNU, VBL, 5-FU, and MTX) were solely capable of inducing a $\sim 50 \%$ growth reduction, little improvements in their cytotoxic activity were observed with PDF, except for a $\sim 90 \%$ cell viability reduction with the $\mathrm{BCNU} / \mathrm{PDF}$ combination. No significant growth/viability reduction was yet seen with VP-16, CPL, CyP, or Mit.C alone or in combination with PDF in $72 \mathrm{~h}$. Nevertheless, the PDF/VC combination certainly induced $>90 \%$ cell viability reduction, which was far better than all dugs tested except BCNU. Thus, these results suggest that the PDF/VC combination appears to be more effective than various chemotherapeutic drugs currently being used in clinical cases. It is also possible that potentiation of BCNU cytotoxicity with PDF may imply its selective chemosensitizing effect, capable of improving the efficacy of certain chemotherapeutic drugs.

\section{Possible potentiation of other natural agents with VC}

Although no chemotherapeutic drugs seem to be potentiated with $\mathrm{VC}$ as seen above, we kept exploring if any other natural

\section{A) Control}

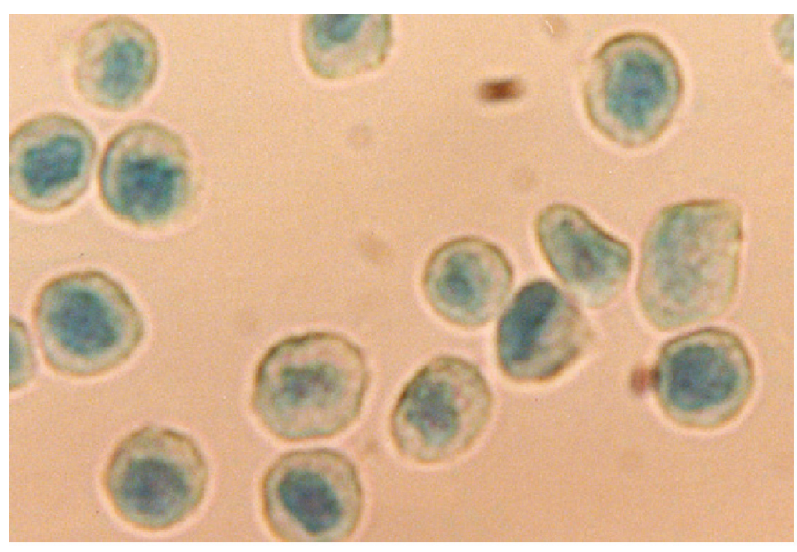

\section{B) PDF/VC-treated}

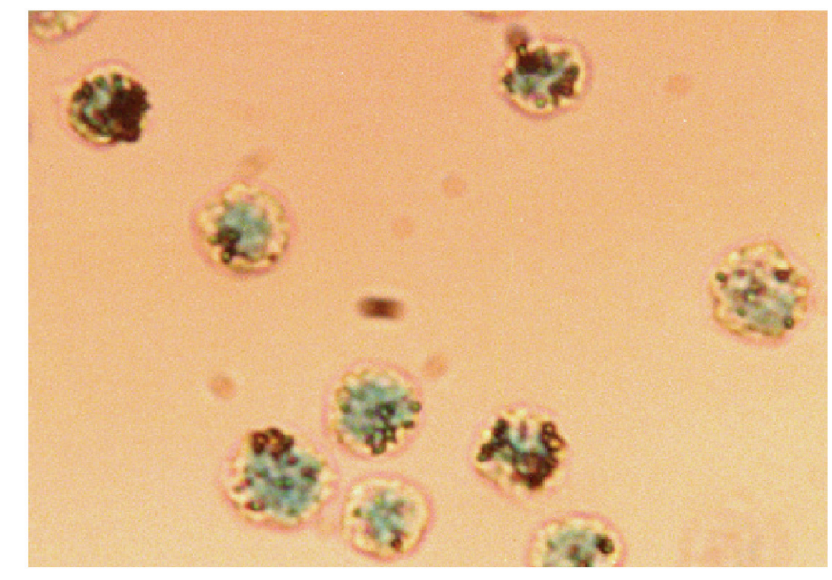

Figure $\mathbf{6}$ In situ hybridization assay. Cells were treated with the combination of PDF $(150 \mu \mathrm{g} / \mathrm{ml})$ and VC $(200 \mu \mathrm{M})$ for $24 \mathrm{~h}$ and evaluated for apoptosis using ISH assay. A minimum of 100 cells from control and PDF/VC-treated cells were counted and assessed for staining. Over $90 \%$ (92/100) of PDF/VC-treated cells (B) were positively stained (with brown color), while $>90 \%(93 / 100)$ of control cells $(\mathbf{A})$ were negative for a stain (giving off green color).

Abbreviations: PDF, Maitake D-fraction; VC, vitamin C. 
Table 4 Comparison of cytotoxic effects of PDF/VC combination, chemotherapeutic drugs alone or in combination with PDF or VCa in PC-3 cells

\begin{tabular}{|c|c|c|c|}
\hline \multirow[t]{2}{*}{ Additions } & \multicolumn{2}{|c|}{ Cell viability (\%) ${ }^{a}$} & \multirow{2}{*}{$\begin{array}{l}\text { Differences } \\
\text { between groups }\end{array}$} \\
\hline & No additions & PDF $(150 \mu \mathrm{g} / \mathrm{ml})$ & \\
\hline No additions & $100 \%$ & $100 \%$ & $N / S^{b}$ \\
\hline$+\mathrm{VC}(200 \mu \mathrm{M})$ & $95 \pm 4.2$ & $4.7 \pm 1.3$ & $p<0.001$ \\
\hline +BCNU $(50 \mu \mathrm{M})$ & $48 \pm 4.9$ & $\mathrm{II} \pm 2.7$ & $p<0.01$ \\
\hline +VBL (100 nM) & $50 \pm 5.8$ & $50 \pm 4.1$ & $N / S$ \\
\hline$+5-\mathrm{FU}(5 \mu \mathrm{g} / \mathrm{ml})$ & $53 \pm 5.2$ & $52 \pm 4.7$ & $\mathrm{~N} / \mathrm{S}$ \\
\hline$+\operatorname{MTX}(100 \mu \mathrm{M})$ & $55 \pm 3.6$ & $53 \pm 5.0$ & $\mathrm{~N} / \mathrm{S}$ \\
\hline +VP-16 (100 nM) & 100 & 100 & $N / S$ \\
\hline$+\mathrm{CPL}(100 \mu \mathrm{M})$ & 100 & $94 \pm 2.0$ & $N / S$ \\
\hline+ CyP $(300 \mu \mathrm{g} / \mathrm{ml})$ & 100 & $95 \pm 1.6$ & $\mathrm{~N} / \mathrm{S}$ \\
\hline +Mit.C (300 nM) & 100 & 100 & $\mathrm{~N} / \mathrm{S}$ \\
\hline
\end{tabular}

Notes: "All cell viability data (\%) are mean \pm SD of three separate experiments; ' $N / S$ indicates that differences in cell viability between "No additions" and "PDF" are not statistically significant.

Abbreviations: BCNU, I,3-bis(2-chloroethyl)-I-nitrosourea (carmustine);VBL, vinblastine; 5-FU, 5-fluorouracil; MTX, methotrexate; VP-I6, etoposide; CPL, cisplatin; Cyp, cyclophosphamide; Mit.C, mitomycin C; PDF, Maitake D-fraction.

products/agents besides PDF might be potentiated with VC. The following nine products were commercially obtained and used in this study:

- ABE: Agaricus blazei Murill mushroom extract

- HMM: Himematsutake (Iwade Strain 101) extract

- STM: Shiitake (Lentinus edodes) mushroom extract

- RGM: Reishi (Ganoderma lucidum) mushroom extract

- ASC: Mixed powder of Agaricuc blazei Murill and shark cartilage

- MSK: Mixed powder of three different mushrooms and three herbs

- AHC: Mycelial extracts of several mushrooms

- ARBX: Arabinoxylan from rice bran

- YBG: Yeast cell wall extract (supplemented with vitamin C)

PC-3 cells were cultured with the varying concentrations $(0-1,000 \mu \mathrm{g} / \mathrm{ml})$ of these extracts with or without VC $(200 \mu \mathrm{M})$ and their effects on cell growth were assessed in $72 \mathrm{~h}$. PDF $(150 \mu \mathrm{g} / \mathrm{ml})$ was also included serving as a positive control, capable of inducing $>90 \%$ cell death with VC. Six products, such as ABE, HMM, ASC, MSK, AHC, and ARBX, had no effects on PC-3 cell growth even at a maximal dose of 1,000 $\mu \mathrm{g} / \mathrm{ml}$, whereas STM, RGM, and YBG showed $\sim 20 \%,>50 \%$, and $>90 \%$ reduction in cell viability, respectively (Table 5). However, it must be noted with caution that such profound cytotoxicity of $Y B G$ could have been due primarily to "VC" supplemented in this product. For PC-3 cells, VC by itself was found to have significant cytotoxic effects when its concentrations went beyond $500 \mu \mathrm{M}$ (Figure 3 ). According to our calculation, we would estimate that " $20 \mu \mathrm{g} / \mathrm{ml}$ " of YBG used to exhibit such potent cytotoxicity has actually contained $2400 \mu \mathrm{M}$ of VC, which was apparently a lethal dose for PC-3 cells. It is thus feasible that YBG-induced cytotoxicity is most likely attributed to the excess amount of VC supplement, not to its active ingredient ( $\beta$-glucan). Pure $\beta$-glucan (present in YBG) is then required for testing its cytotoxic effect on PC-3 cells, so that YBG has been dismissed from this study.

When these extracts were combined with VC $(200 \mu \mathrm{M})$, most of them failed to show any enhanced cytotoxicity, except for STM and RGM at $150 \mu \mathrm{g} / \mathrm{ml}$ exhibiting 50\% and 90\% cell viability reduction, respectively (Table 5). Thus, the combination of PDF and VC appears to yet have the most potent cytotoxic effect on PC-3 cells, inducing $>90 \%$ cell viability reduction; however, enhanced cytotoxicity of STM and RGM with VC suggests that some other natural agents/products could be also potentiated with VC. Moreover, it should be noted that the effectiveness of various mushroom extracts (glucans or polysaccharides) is known to be cancer-specific despite their structural and functional similarities. ${ }^{68}$ Some other natural extracts besides mushrooms are also shown to have cancer specificity. Therefore, it cannot rule out the possibility that some of natural agents tested above with little effects could be highly effective on certain malignancies besides prostate cancer. Studies of those natural agents on a variety of cancer cells are then warranted. 
Table 5 Effects of various natural agents and their combination with VC on PC-3 cells

\begin{tabular}{lll}
\hline Natural agents & \multicolumn{2}{c}{ Cell growth/viability $(\%)$} \\
\cline { 2 - 3 } & No additions & + VC $(\mathbf{2 0 0} \mu \mathbf{M})$ \\
\hline ABE & $100 \%$ & $100 \%$ \\
HMM & 100 & 100 \\
STM $^{a}$ & $\sim 80$ & $\sim 50$ \\
RGM $^{a}$ & $\sim 47$ & $\sim 10$ \\
ASC & 100 & 100 \\
MSK & 100 & 100 \\
AHC & 100 & 100 \\
ARBX & 100 & 100 \\
YBG & $<5$ & N/A \\
PDF & 100 & $\sim 10$ \\
\hline
\end{tabular}

Notes: aFive hundred $\mu \mathrm{g} / \mathrm{ml}$ each of STM and RGM was used solely while I $50 \mu \mathrm{g} / \mathrm{ml}$ each of these agents (in comparison with PDF) was used for VC $(200 \mu \mathrm{M})$ combination study, but this VC alone had no effects. For the rest of agents (excluding YBG), a maximum concentration of $1,000 \mu \mathrm{g} / \mathrm{ml}$ was tested solely and in combination with VC; ${ }^{\text {CC }}$ oncentration of YBG used here was $20 \mu \mathrm{g} / \mathrm{ml}$ based on the amount of $\beta$-glucan, but it also contained the estimated, lethal dose of 2,400 $\mu \mathrm{M}$ VC.Accordingly, YBG has been dismissed from this study and see the text for further explanation.

Abbreviations: ABE, Agaricus blazei Murill mushroom extract; HMM, Himematsutake (Iwade Strain 10I) extract; STM, Shiitake (Lentinus edodes) mushroom extract; RGM, Reishi (Ganoderma lucidum) mushroom extract;ASC, Mixed powder of Agaricuc blazei Murill and shark cartilage; MSK, Mixed powder of 3 different mushrooms and 3 herbs; AHC, Mycelial extracts of several mushrooms; ARBX, Arabinoxylan from rice bran; YBG, Yeast cell wall extract; N/A, not applicable.

\section{Cytotoxic effect of PDF/VC combination on other cancer cells}

Since we have been working only on prostate cancer (PC-3) cells, it would be feasible to raise the question on whether the $\mathrm{PDF} / \mathrm{VC}$ combination could be also effective on any cancers other than prostate cancer. This possibility was then tested using various human cancer cells including bladder (T24), kidney (ACHN), breast (MCF-7), lung (A549), stomach (AGS), liver (HepG2), brain (U-89), and leukemia (HL-60) cells. Additionally, as it was of interest to examine possible effects of PDF/VC combination on "nonhuman" cancers, three canine cancer cells such as mammary gland (CF33), connective tissue (CF21), and lymphoma (CL-1) cells were also included in this study.

\section{PDF/VC effects on human cancer cells}

All human cancer cells were cultured with the varying concentrations $(0-1,000 \mu \mathrm{g} / \mathrm{ml})$ of PDF alone or in combination with VC $(200 \mu \mathrm{M})$ for 24 to $72 \mathrm{~h}$. Cell number/viability was determined at specified times and summarized in Table 6. No effects on ACHN, A549, and AGS cells were detected even with $1,000 \mu \mathrm{g} / \mathrm{ml}$ of PDF in $72 \mathrm{~h}$, while some but insignificant ( $10 \%)$ growth inhibition was seen in both MCF-7 and HepG2 cells with PDF $(1,000 \mu \mathrm{g} / \mathrm{ml})$.
Table 6 Effects of PDF alone and its combination with VC on various cancer cells

\begin{tabular}{lll}
\hline Cancer cells & \multicolumn{2}{c}{ Growth inhibition (\%) } \\
\cline { 2 - 3 } & + PDF $^{\mathrm{a}}$ & +PDF/VC \\
\hline T24 (bladder) & $\sim 50 \% \mathrm{CD}$ with PDF $(500 \mu \mathrm{g} / \mathrm{ml})$ & $>95 \% \mathrm{CD}$ \\
& $>95 \% \mathrm{CD}$ with PDF $(\mathrm{I}, 000)$ & \\
ACHN (kidney) & $\mathrm{N} / \mathrm{E}$ & $\mathrm{N} / \mathrm{E}$ \\
MCF-7 (breast) & $\sim 10 \% \mathrm{Gl}$ with PDF $(\mathrm{I}, 000)$ & $\sim 50 \% \mathrm{Gl}$ \\
A549 (lung) & $\mathrm{N} / \mathrm{E}$ & $\mathrm{N} / \mathrm{E}$ \\
AGS (gastric) & $\mathrm{N} / \mathrm{E}$ & $\mathrm{N} / \mathrm{E}$ \\
HepG2 (liver) & $\sim 10 \% \mathrm{Gl}$ with PDF $(\mathrm{I}, 000)$ & $\sim 50 \% \mathrm{Gl}$ \\
U-87 (brain) & $\sim 90 \% \mathrm{Gl}$ with PDF $(250)$ & $>95 \% \mathrm{CD}$ \\
& $>90 \% \mathrm{Gl}$ with PDF $(500)$ & \\
HL-60 (leukemia) & $\sim 50 \% \mathrm{CD}$ with PDF $(250)$ & $>95 \% \mathrm{CD}$ \\
& $\sim 90 \% \mathrm{CD}$ with PDF $(500)$ & \\
\hline
\end{tabular}

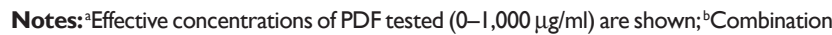
of PDF $(150 \mu \mathrm{g} / \mathrm{ml})$ and VC $(200 \mu \mathrm{M})$ was tested, but this VC alone had no effects. Abbreviations: $C D$, cell death; GI, growth inhibition; N/E, no effects; PDF, Maitake D-fraction.

In contrast, PDF demonstrated its cytotoxic effect on T24, U-87, and HL-60 cells. T24 cells showed nearly 50\% and complete cell death in $72 \mathrm{~h}$ with 500 and $1,000 \mu \mathrm{g} / \mathrm{ml} \mathrm{PDF}$, respectively. Almost $90 \%$ growth inhibition (without cell death) was attained in U-87 cells with $250 \mu \mathrm{g} / \mathrm{ml}$ PDF in $72 \mathrm{~h}$, while $>90 \%$ growth inhibition was achieved with $500 \mu \mathrm{g} / \mathrm{ml}$ PDF in only $24 \mathrm{~h}$. Nearly $50 \%$ and $90 \%$ of HL-60 cells were dead in $24 \mathrm{~h}$ with 250 and $500 \mu \mathrm{g} / \mathrm{ml}$ PDF, respectively. Thus, PDF may exhibit antiproliferative or cytotoxic activity in a cancer-specific manner: overall, PDF indeed demonstrated its cellular effects on five of eight human cancer cells tested.

These cancer cells were next cultured with the combination of PDF $(150 \mu \mathrm{g} / \mathrm{ml})$ and $\mathrm{VC}(200 \mu \mathrm{M})$ for $24 \mathrm{~h}$ to assess their responses (if any) or susceptibility to this specific regimen (established for PC-3 cells). Our pilot study already confirmed that $200 \mu \mathrm{M}$ VC alone had no effects on all eight cancer cells used here. Table 6 also shows that no effects of this PDF/VC combination were seen in the same three cancer cells such as ACHN, A549, and AGS cells; however, a 50\% growth inhibition was now induced in MCF-7 and HepG2 cells with this combination. On the other hand, T24, U-87, and HL-60 cells all resulted in almost complete cell death (>95\%) following the PDF/VC treatment. Thus, these results show that T24, U-87, and HL-60 cells seem to be rather vulnerable to the PDF/VC combination just as PC-3 cells, while MCF-7 and HepG2 cells may have some susceptibility. The rest of three cancer cells show little responses to this combination regimen. 
Table 7 Effects of PDF alone and its combination with VC on canine cancer cells

\begin{tabular}{lll}
\hline $\begin{array}{l}\text { Canine cancer } \\
\text { cells }\end{array}$ & \multicolumn{2}{c}{ Growth inhibition (\%) } \\
\cline { 2 - 3 } & + PDF $^{\mathrm{a}}$ & + PDF/VC \\
\hline CF33 & $\sim 40 \% \mathrm{Gl}$ with PDF $(500 \mu \mathrm{g} / \mathrm{ml})$ & $\sim 90 \% \mathrm{CD}$ \\
(mammary gland) & $\sim 65 \% \mathrm{Gl}$ with PDF $(\mathrm{I}, 000)$ & \\
CF2I & $\sim 30 \% \mathrm{Gl}$ with PDF $(500)$ & $\sim 90 \% \mathrm{CD}$ \\
(connective tissue) & $\sim 70 \% \mathrm{Gl}$ with PDF $(\mathrm{I}, 000)$ & \\
CL-I & $\sim 20 \% \mathrm{CD}$ with PDF $(500)$ & $>95 \% \mathrm{CD}$ \\
(lymphoma) & $>90 \% \mathrm{CD}$ with PDF $(1,000)$ & \\
\hline
\end{tabular}

Notes: affective concentrations of PDF tested $(0-1,000 \mu g / m l)$ are shown; ${ }^{b}$ Combination of PDF $(150 \mu \mathrm{g} / \mathrm{ml})$ and VC $(200 \mu \mathrm{M})$ was tested, but this VC alone had no effects. Abbreviations: $\mathrm{Gl}$, growth inhibition; $\mathrm{CD}$, cell death; PDF, Maitake D-fraction.

These findings further suggest that the PDF/VC combination (as well as PDF alone) appears to somewhat act in a cancerspecific manner.

\section{PDF/VC effects on canine cancer cells}

Three types of canine cancer cells, canine mammary gland cancer (CF33), connective tissue cancer (CF21), and lymphoma (CL-1) cells, ${ }^{69}$ were cultured with varying concentrations $(0-1,000 \mu \mathrm{g} / \mathrm{ml})$ of PDF alone or in combination with $\mathrm{VC}$ $(200 \mu \mathrm{M})$, and cell number/viability was assessed at specified times. The results are then summarized in Table 7 . In $72 \mathrm{~h}$, 500 and $1,000 \mu \mathrm{g} / \mathrm{ml}$ of PDF led to $\sim 40 \%$ and $\sim 65 \%$ growth reduction in CF33 cells while $\sim 30 \%$ and $\sim 70 \%$ growth reduction in CF21 cells, respectively. In contrast, CL-1 cells appeared to be more susceptible to PDF, because $~ 20 \%$ and $>90 \%$ of these cells were dead in $24 \mathrm{~h}$ with 500 and $1,000 \mu \mathrm{g} / \mathrm{ml} \mathrm{PDF}$, respectively. Thus, PDF seems to induce the growth inhibition or cell death in all three canine cancer cells, although it would require the relatively high concentrations ( 500 or $1,000 \mu \mathrm{g} / \mathrm{ml}$ ) of PDF to be effective.

When these cancer cells were cultured with the combination of PDF $(150 \mu \mathrm{g} / \mathrm{ml})$ and VC $(200 \mu \mathrm{M})$ for $24 \mathrm{~h}$, both CF33 and CF 21 cells showed a $~ 90 \%$ growth reduction while all CL-1 cells were found to be completely dead (Table 7). Taken together, PDF alone or its combination with VC demonstrates significant antiproliferative or cytotoxic activity on three canine cancer cells, implying that PDF may work on human cancers as well as canine and other veterinary cancers crossing a species barrier.

\section{Conclusions}

A number of in vitro and in vivo studies and limited clinical studies have demonstrated potent immunomodulatory and antitumor activities of PDF or Maitake D-fraction, implying its great potential in cancer treatment and prevention. Particularly synergistic potentiation of PDF with VC may further help improve the efficacy of currently ongoing treatments for various cancers. Although iv administration of VC could be an interesting and useful procedure, more clinical studies are required for assessing its safety and efficacy in cancer patients. It is also interesting that PDF may not only alleviate various side effects and improve quality of life of patients under chemotherapy but also have possible chemosensitizing effect to improve the efficacy of chemotherapy. However, as more comprehensive and controlled studies are required for the clinical demonstration of PDF, the active participation of physicians and professional health care providers in such studies is advised to properly and timely evaluate PDF for cancer therapy.

\section{Acknowledgments}

I would like to thank Mr Mike Shirota (Maitake Products, Inc.) for generously providing PDF and personal support and all residents of our department who participated in these studies. In particular, I am grateful to Dr Muhammad Choudhury, our Department Chairman, for his commitment to support the entire project. There are no conflicts of interest in this work.

\section{References}

1. Shirota M. What do you know about medicinal mushrooms. Explore. 1996;7:48-52.

2. Wasser SP, Nevo E, Sokolov D, Reshetnikov S, Timor-Tismenetsky M. Dietary supplements from medicinal mushrooms: diversity of types and variety of regulations. Int J Med Mushr. 2000;2:1-19.

3. Mizuno T, Zhuang C. Maitake, Grifola frondosa: pharmacological effects. Food Rev Int. 1995;11:135-149.

4. Manohar V, Talpur NA, Echard BW, Lieberman S, Preuss HG. Effects of a water-soluble extract of maitake mushroom on circulating glucose/insulin concentrations in KK mice. Diabetes Obes Metab. 2002;4:43-48.

5. Kubo K, Aoki H, Nanba H. Anti-diabetic activity present in the fruit body of Grifola frondosa (maitake). Biol Pharm Bull. 1994;17:1106-1110.

6. Kubo K, Nanba H. The effect of maitake mushrooms on liver and serum lipids. Altern Ther Health Med. 1996;2:62-66.

7. Jones K. Maitake, a potent medicinal food. Altern Complement Ther. 1998;4:420-429.

8. Kabir Y, Yamaguchi M, Kimura S. Effect of shiitake (Lentinus edodes) and maitake (Grifola frondosa) mushrooms on blood pressure and plasma lipids of spontaneously hypertensive rats. J Nutr Sci Vitaminol (Tokyo). 1987;33:341-346.

9. Adachi K, Nanba H, Otsuka M, Kuroda H. Blood pressure-lowering activity present in the fruit body of Grifola frondosa. Chem Pharm Bull. 1988;36:1000-1006.

10. Nakai R, Masui H, Horio H, Ohtsuru M. Effect of maitake (Grifola frondosa) water extract on inhibition of adipocyte conversion of C3H10T1/ 2B2C1 cells. J Nutr Sci Vitaminol (Tokyo). 1999;45:385-389.

11. Gu CQ, Li JW, Chao FH. Inhibition of hepatitis B virus by D-fraction from Grifola frondosa: synergistic effect of combination with interferon- $\alpha$ in HepG2 2.2.15. Antiviral Res. 2006;72:162-165. 
12. Developmental Therapeutics Program, National Cancer Institute. In-vitro anti-HIV drug screening results. NSC: F195001, Jan 1992.

13. Nanba $\mathrm{H}$, Hamaguchi A, Kuroda $\mathrm{H}$. The chemical structure of an antitumor polysaccharide in fruit bodies of Grifola frondosa (maitake). Chem Pharm Bull. 1987;35:1162-1168.

14. Wasser SP. Medicinal mushrooms as a source of antitumor and immunomodulating polysaccharides. Appl Microbiol Biotechnol. 2002;60:258-274.

15. Lull C, Wichers HJ, Savelkoul HF. Antiinflammatory and immunomodulating properties of fungal metabolites. Mediators Inflamm. 2005;2:63-80.

16. Williams DL, Mueller A, Browder W. Glucan-based macrophage stimulators. Clin Immunother. 1996;5:392-399.

17. Brown GD, Gordon S. Fungal beta-glucans and mammalian immunity. Immunity. 2003;19:311-315.

18. Brown GD, Gordon S. Immune recognition of fungal $\beta$-glucans. Cell Microbiol. 2005;7:471-479.

19. Taylor PR, Brown GD, Reid DM, et al. The beta-glucan receptor, Dectin-1, is predominantly expressed on the surface of cells of the monocyte/macrophage and neutrophil lineages. J Immunol. 2002;269:3876-3882.

20. Brown GD, Herre J, Williams DL, Willment JA, Marshall AS, Gordon S. Dectin-1 mediates the biological effects of beta-glucan. J Exp Med. 2003;197:1119-1124.

21. Lin H, She YH, Cassileth BR, Sirotnak F, Cunningham Rundles S. Maitake beta-glucan MD-fraction enhances bone marrow colony formation and reduces doxorubicin toxicity in vitro. Int Immunopharmacol. 2004;4:91-99.

22. Lin H, Cheung SWY, Nesin M, Cassileth BR, Cunningham Rundles S. Enhancement of umbilical cord blood cell hematopoiesis by maitake beta-glucan is mediated by granulocyte colony-stimulating factor production. Clin Vaccine Immunol. 2007;14:21-27.

23. de Chastellier C, Berche P. Fate of Listeria monocytogenes in murine macrophages: evidence for simultaneous killing and survival of intracellular bacteria. Infect Immun. 1994;62:543-553.

24. Kodama N, Yamada M, Nanba H. Addition of maitake D-fraction reduces the effective dosage of vancomycin for the treatment of Listeriainfected mice. Jpn J Pharmacol. 2001;87:327-332.

25. Sanzen I, Imanishi N, Takamatsu N, et al. Nitric oxide-mediated antitumor activity induced by the extract from Grifola frondosa (Maitake mushroom) in a macrophage cell line, RAW264.7. J Exp Clin Cancer Res. 2001;20:591-597.

26. Nanba H. Maitake D-fraction: healing and preventive potential for cancer. J Orthomol Med. 1997;12:43-49.

27. Miller JS. Biology of natural killer cells in cancer and infection. Cancer Invest. 2002;20:405-419.

28. Sepulveda C, Puente J. Natural killer cells and the innate immune system in infectious pathology. Rev Med Chil. 2000;128:1361-1370.

29. Kodama N, Komuta K, Sakai N, Nanba H. Effects of D-fraction, a polysaccharide from Grifola frondosa, on tumor growth involve activation of NK cells. Biol Pharm Bull. 2002;25:1647-1650.

30. Kodama N, Komuta K, Nanba H. Effect of Maitake (Grifola frondosa) $\mathrm{D}$-fraction on the activation of NK cells in cancer patients. J Med Food. 2003;6:371-377.

31. Kodama N, Murata Y, Nanba H. Administration of a polysaccharide from Grifola frondosa stimulates immune function of normal mice. J Med Food. 2004;7:141-145.

32. Mosmann TR, Sad S. The expanding universe of T-cell subsets: Th1, Th2 and more. Immunol Today. 1996;17:138-146.

33. Inoue A, Kodama N, Nanba H. Effect of Maitake (Grifola frondosa) D-fraction on the control of the T lymph node Th-1/Th-2 proportion. Biol Pharm Bull. 2002;25:536-540.

34. Kodama N, Harada N, Nanba H. A polysaccharide, extract from Grifola frondosa, induces Th-1 dominant responses in carcinoma-bearing BALB/c mice. Jpn J Pharmacol. 2002;90:357-360.

35. Harada N, Kodama N, Nanba H. Relationship between dendritic cells and the D-fraction-induced Th-1 dominant response in BALB/c tumorbearing mice. Cancer Lett. 2003;192:181-187.
36. Deng G, Lin H, Seidman A, et al. A phase I/II trial of a polysaccharide extract from Grifola frondosa (Maitake mushroom) in breast cancer patients: immunological effects. J Cancer Res Clin Oncol. 2009 Mar 1. [Epub ahead of print].

37. Glauco S, Jano F, Paolo G, Konno S. Safety of maitake D-fraction in healthy patients: assessment of common hematologic parameters. Altern Complement Ther. 2004;10:228-230.

38. Ohno N, Iino K, Takeyama T, et al. Structural characterization and antitumor activity of the extracts from matted mycelium of cultured Grifola frondosa. Chem Pharm Bull. 1985;33:3395-3401.

39. Nanba H. Antitumor activity of orally administered D-fraction from maitake mushroom. J Naturopathic Med. 1993;4:10-15.

40. Nanba H.: Activity of Maitake D-fraction to inhibit carcinogenesis and metastasis. Ann N Y Acad Sci. 1995;768:243-245.

41. Nanba H. Effect of Maitake D-fraction on cancer prevention. Ann N $Y$ Acad Sci. 1997;833:204-207.

42. Nanba $H$. Results of non-controlled clinical study for various cancer patients using Maitake D-fraction. Explore. 1995;6:19-21.

43. Maitake Products Inc. Maitake D-fraction obtained IND for clinical study. Paramus, NJ: Maitake Products, Inc.; Feb 1998.

44. Konno S. Maitake D-fraction: a potent mushroom extract product against human malignancies. Townsend Lett. 2002;233:96-100.

45. Gleason DF, Mellinger GT. Prediction of prognosis for prostatic adenocarcinoma by combined histological grading and clinical staging. J Urol. 1974;111:58-64.

46. Carr A, Frei B. Does vitamin $\mathrm{C}$ act as a pro-oxidant under physiological conditions? FASEB J. 1999;13:1007-1024.

47. Buettner G, Jurkiewicz B. Catalytic metals, ascorbate and free radicals: combinations to avoid. Radit Res. 1996;145:532-541.

48. Clement M, Ramalingam J, Long L, Halliwell B. The in vitro cytotoxicity of ascorbate depends on the culture medium used to perform the assay and involves hydrogen peroxide. Antioxid Redox Signal. 2001;3: 157-163.

49. Chen Q, Espey M, Sun A, et al. Ascorbate in pharmacologic concentrations selectively generates ascorbate radical and hydrogen peroxide in extracellular fluid in vivo. Proc Natl Acad Sci U S A. 2007;104:49-54.

50. Chen Q, Espey M, Krishna M, et al. Pharmacologic ascorbic acid concentrations selectively kill cancer cells: action as a pro-drug to deliver hydrogen peroxide to tissues. Proc Natl Acad Sci U S A. 2005;102:13604-13609.

51. Taper H, de Gerlache J, Lans M, Roberfroid M. Non-toxic potentiation of cancer chemotherapy by combined $\mathrm{C}$ and $\mathrm{K} 3$ vitamin pre-treatment. Int J Cancer. 1987;40:575-579.

52. Pathak A, Bhutani M, Guleria R, et al. Chemotherapy alone vs chemotherapy plus high dose multiple antioxidants in patients with advanced non-small cell lung cancer. $J$ Am Coll Nutr. 2005;24:16-21.

53. Creagan E, Moertel C, O'Fallon J, et al. Failure of high-dose vitamin $\mathrm{C}$ (ascorbic acid) therapy to benefit patients with advanced cancer: a controlled trial. $N$ Engl J Med. 1979;301:687-690.

54. Levine M, Conry-Cantilena C, Wang Y, et al. Vitamin C pharmacokinetics in healthy volunteers: evidence for a recommended dietary allowance. Proc Natl Acad Sci U S A. 1996;93:3704-3709.

55. Hoffer L, Levine M, Assouline S, et al. Phase I clinical trial of i.v. ascorbic acid in advanced malignancy. Ann Oncol. 2008;19:1969-1974.

56. Morishige $\mathrm{F}$. The role of vitamin $\mathrm{C}$ in tumor therapy (human). In: Meyskens FI Jr, Parasad KN, editors. Vitamins and Cancer: Human Cancer Prevention by Vitamins and Micronutrients. Clifton, NJ: Humana Press; 1986. p. 399-427.

57. Fullerton SA, Samadi AA, Tortorelis DG, et al. Induction of apoptosis in human prostatic cancer cells with $\beta$-glucan (maitake mushroom polysaccharide). Mol Urol. 2000;4:7-11.

58. Zerbib M, Zelefsky MJ, Higano CS, Carroll PR. Conventional treatments of localized prostate cancer. Urology. 2008;72:25-35.

59. Kreis W. Current chemotherapy and future directions in research for the treatment of advanced hormone-refractory prostate cancer. Cancer Invest. 1995;13:296-312. 
60. Kaighn ME, Narayan KS, Ohnuki Y, Lechner JF, Jones LW. Establishment and characterization of a human prostate carcinoma cell line (PC-3). Invest Urol. 1979;17:16-23.

61. Malorni W, Iosi F, Mirabelli F, Bellomo G. Cytoskeleton as a target in menedione-induced oxidative stress in cultured mammalian cells: alterations underlying surface bleb formation. Chem Biol Interact. 1991;80:217-236.

62. Dargel R. Lipid peroxidation: a common pathogenetic mechanism? Exp Toxicol Pathol. 1992;44:169-181.

63. De Laurenzi V, Melino G, Savini I, Annicchiarico-Petruzzelli M, Finazzi-Agro A, Avigliano L. Cell death by oxidative stress and ascorbic acid regeneration in human neuroectodermal cell lines. Eur J Cancer. 1995;31A:463-466.

64. Leung PY, Miyashita K, Young M, Tsao CS. Cytotoxic effect of ascorbate and its derivatives on cultured malignant and nonmalignant cell lines. Anticancer Res. 1993;13:475-480.
65. Sinha BK, Mimnaugh EG. Free radicals and anticancer drug resistance: oxygen free radicals in the mechanisms of drug cytotoxicity and resistance by certain tumors. Free Radic Biol Med. 1990;8:567-581.

66. Gavrieli Y, Sherman Y, Ben-Sasson SA. Identification of programmed cell death in situ via specific labeling of nuclear DNA fragmentation. J Cell Biol. 1992;119:493-501.

67. Theyer G, Hamilton G. Role of multidrug resistance in tumors of the genitourinary tract. Urology. 1994;44:942-950.

68. Borchers AT, Stern JS, Hackman RM. Mushrooms, tumors and immunity. Proc Soc Exp Biol Med. 1999;221:281-293.

69. Konno S. Potential growth inhibitory effect of maitake D-fraction on canine cancer cells. Vet Ther. 2004;5:263-271.

\section{Publish your work in this journal}

The International Journal of General Medicine is an international, peer-reviewed open-access journal that focuses on general and internal medicine, pathogenesis, epidemiology, diagnosis, monitoring and treatment protocols. The journal is characterized by the rapid reporting of reviews, original research and clinical studies across all disease areas.
A key focus is the elucidation of disease processes and management protocols resulting in improved outcomes for the patient.The manuscript management system is completely online and includes a very quick and fair peer-review system. Visit http://www.dovepress.com/ testimonials.php to read real quotes from published authors.

Submit your manuscript here: http://www.dovepress.com/international-journal-of-general-medicine-journal 